\title{
PORTFOLIO DIVERSIFICATION OPPORTUNITIES WITHIN EMERGING AND FRONTIER STOCK MARKETS: EVIDENCE FROM TEN ASIAN COUNTRIES
}

\author{
Seema Narayan ${ }^{1}$, Mobeen Ur Rehman ${ }^{2}$ \\ ${ }^{1}$ School of Economics, Finance and Marketing, RMIT University, Melbourne, \\ Australia. Email: seema.narayan@rmit.edu.au. \\ ${ }^{2}$ Shaheed Zulfikar Ali Bhutto Institute of Science and Technology, Karachi, Pakistan. \\ Email: mobeen.rehman@szabist-isb.edu.pk
}

\begin{abstract}
In this paper, we take the case of Asian investors in any one out of ten Emerging and Frontier Asian (EFA) nations with an investment portfolio comprising of the MSCI of the home country, MSCIs of nine other Asian countries and stock market index of a developed nation. We examine their portfolio diversification opportunities for the period 2000 to 2013 after conditioning for oil price movements and global investor sentiments. Our empirical analyses imply significant opportunities to diversify within Asia. In particular, not all stock markets show a stable long run relationship. The unconditional correlations in the short run and conditioned regression linkages from VECMs are weak and mainly insignificant. Diversification opportunities for investors in some Asian nations improve after hedging for exchange rate movements. Further, we find that the portfolio examined here may lead to greater diversification gains than a portfolio without the nine other Asian countries.
\end{abstract}

Keywords: Co-integration; VECM; Emerging markets; Asia.

JEL Classification: G11; G15; F3; F65.

Article history:

Received : March 2, 2018

Revised : : May 18, 2018

Accepted : June 19, 2018

Available online : July 31, 2018

https://doi.org/10.21098/bemp.v21i1.893 


\section{INTRODUCTION}

Little is known about whether an international investment portfolio covering multiple nations leads to diversifications gains or not - which are by nature shortterm, long-term, or both - for investors. In this paper, we explore diversification opportunity for international portfolios with multiple international emerging and frontier equity market indices.

Our study takes the case of investors who reside in any one of the ten fastgrowing Emerging and Frontier Asian (EFA) nation and has an investment portfolio comprising of the MSCI of his or her nation, nine MSCIs of other EFA nations, and the S\&P 500.

Typically, cointegration technique and an Error Correction Model (ECM) are used to draw out the long-term opportunities and short-run gains, respectively. Thus far, such analysis has mainly been employed for a portfolio comprising typically of two international stock market indices. The 1997-1998 Asian Financial Crisis (AFC) triggered a wave of studies on Asian markets, some of which examined the linkages between Asian stock markets. These studies suggest that the AFC diminished opportunity to diversify within Asia, particularly for those countries most affected by the crisis (see Chiang et al., 2007; Yang, et al., 2003). Recent studies gauging short-term correlations suggest that linkages between selected Asian markets have diminished since the AFC is time varying in nature (Narayan et al., 2014; Phylaktis \& Ravazzolo, 2002). Sriananthakumar \& Narayan (2015) show a lack of dynamic conditional correlations between Sri Lanka and the neighboring Asian countries. Existing studies on short-term diversification gains are based on pairwise relationships and not on a portfolio of Asian nations as covered in the present paper.

As noted above while there are several studies ${ }^{3}$ that examine pairwise longrun diversification opportunities within Asian markets, evidence on a portfolio of Asian markets is either limited or unclear. Only three studies provide some clear link between several Asian stock markets. Batareddy et al., (2012) uses rolling and recursive cointegration to find no case for a cointegrating linkage between the emerging stock markets of India, China, South Korea, and Taiwan. Manning (2002) uses the Johansen cointegration approach to find pairwise cointegration for nine Asian markets for the period 1988-1999. Mukherjee and Bose (2008) find evidence in favor of pair-wise cointegration between seven Asian markets over the period January 1999 to June 2005. Other studies examine emerging markets from different regions, including Asia, but with no clear lessons for diversification within Asia (see Auer, 2016; Kenourgios \& Padhi, 2012).

Our study contributes to the issue of short and long-run linkages by looking at linkages between stock markets in ten Asian countries - emerging and frontier - for the period 2000-2013. Two key differences between our study and previous studies

3 There are many studies that examine integration between emerging and frontier equity markets however we are only focused on studies that are on Asia and use similar technique as us. For a review of stock market integration see Auer (2016); Al Asad Bin Hoque (2017); Jayasuriya (2011); Kenourgios \& Padhi (2012); Mukherjee \& Boss (2008); Narayan (2015); Rehman and Kashif (2018); Rehman et al. (2016). 
on long and short-run linkages, outlined above, are as follows. First, we consider the linkages for ten Asian countries such that each single country is examined against a portfolio of nine Asian stock market indices, in effect giving us ten Asian portfolios. This multilateral approach is unique in examining linkages between emerging and frontier markets because most studies use a bilateral approach, examining the countries in pairs only. ${ }^{4}$ Second, while we use conventional econometric approaches, the long and short-run linkages are conditioned to oil shocks, global investor sentiments, exchange rate movements, and US marketbased shocks, which are found to be important determinants in Asian stock markets. All of the previous studies only account for US market shocks and/or financial crises (see discussion in Section 3).

The remainder of this paper is as follows. The next two sections explain the data and empirical methods. Section four discusses the results, while the final section concludes the study.

\section{DATA}

We use daily Morgan Stanley Capital International (MSCI) indices (all expressed in US dollars) of stock markets in ten Asian countries, namely Bangladesh, China, India, Indonesia, Malaysia, Pakistan, the Philippines, South Korea, Sri Lanka, and Thailand, over the fourteen year period 2000-2013 (Figure 1). This data is sourced from the Thomson Reuters Data Stream Financials.

\section{BANGLADESH}

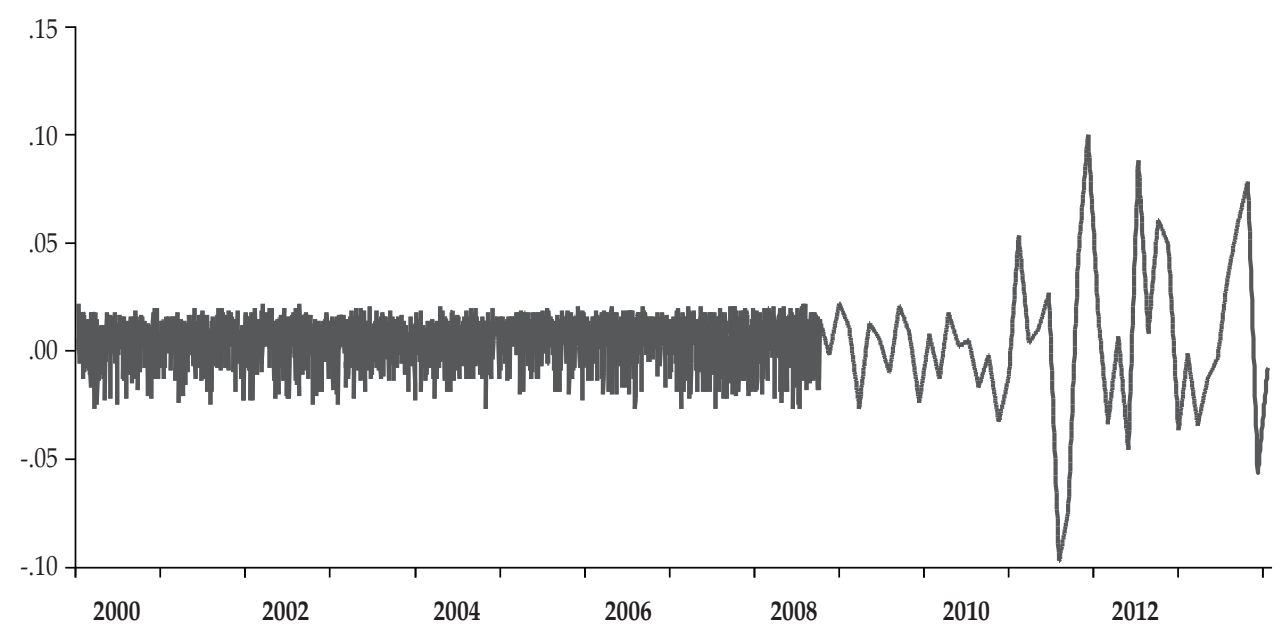

Figure 1.

Returns of Ten Emerging and Frontier Markets

Monthly returns for the emerging and frontier Asian markets are reported in the figure from 2000-2013.

4 of the studies mentioned, only Auer (2016) measures the Hurst coefficient for panels of countries. Further, his study uses an ad hoc panel structure. 

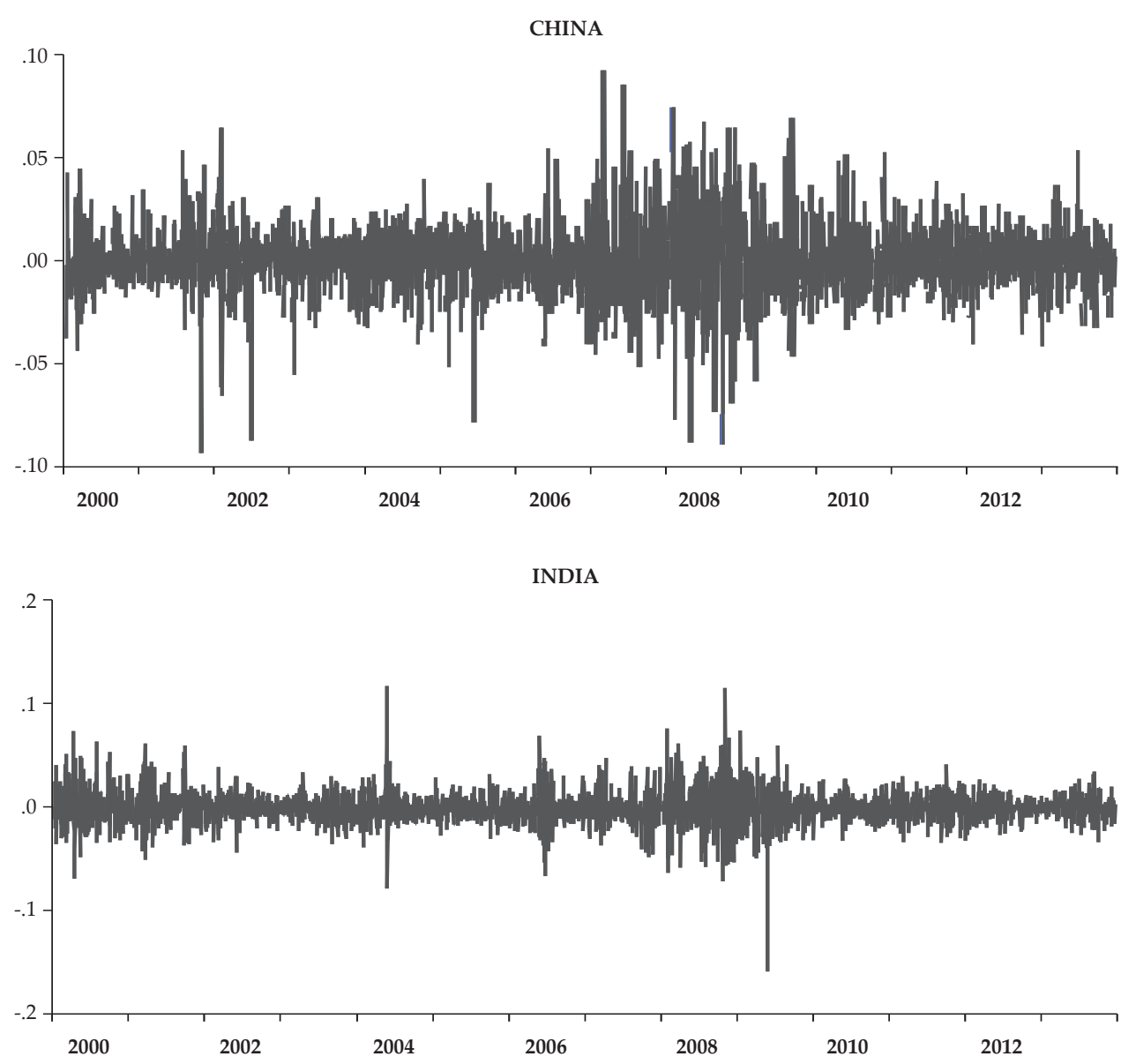

INDONESIA

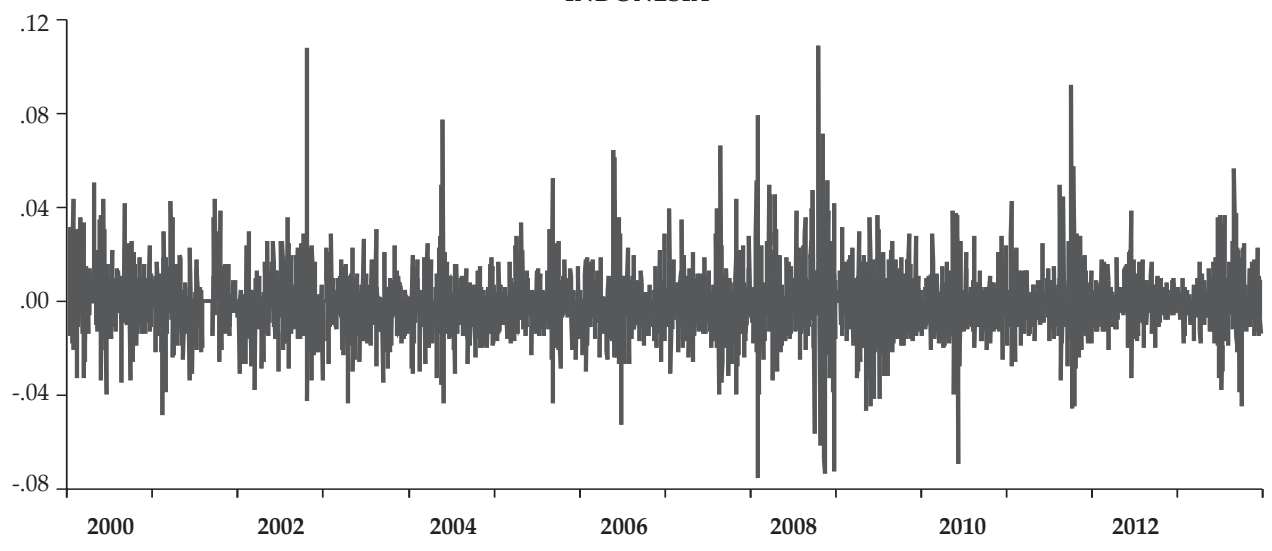

Figure 1.

Returns of Ten Emerging and Frontier Markets

Monthly returns for the emerging and frontier Asian markets are reported in the figure from 2000-2013. (Continued) 

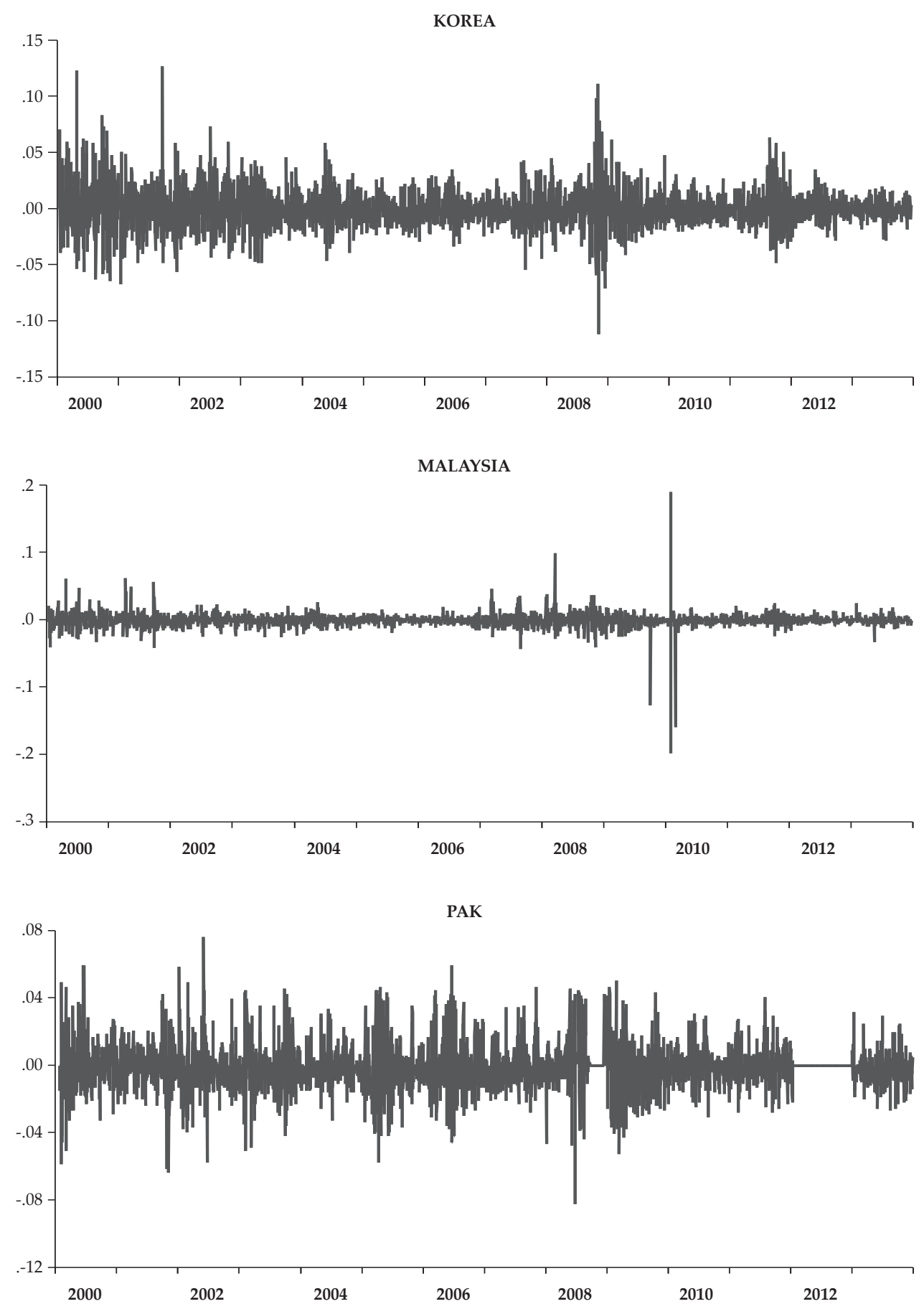

Figure 1.

Returns of Ten Emerging and Frontier Markets

Monthly returns for the emerging and frontier Asian markets are reported in the figure from 2000-2013. (Continued) 
PHILIPPINES

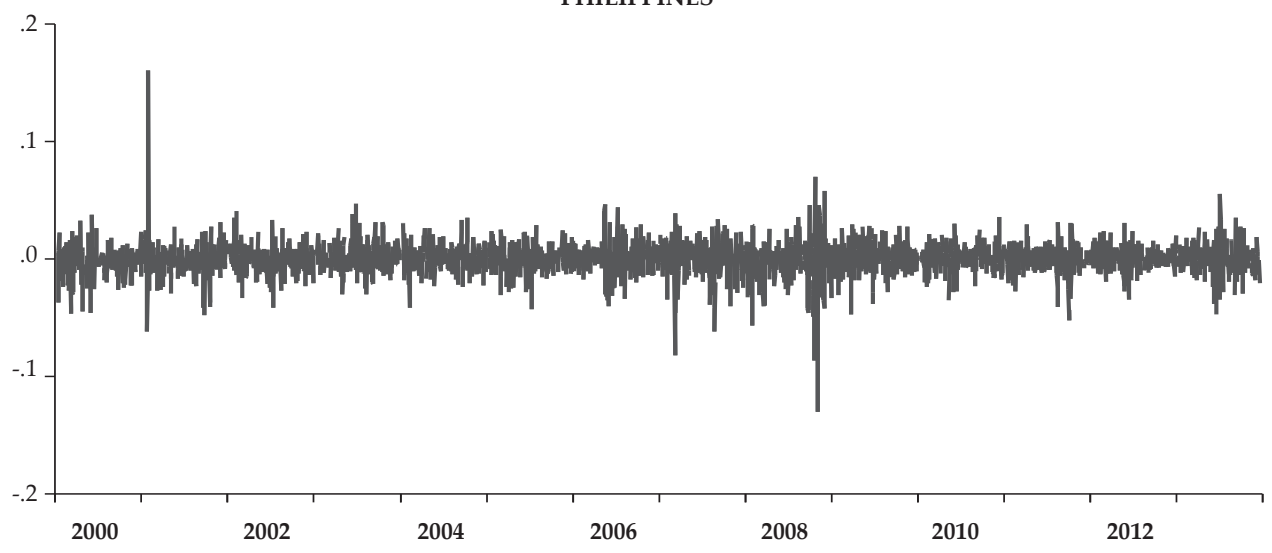

SRI LANKA

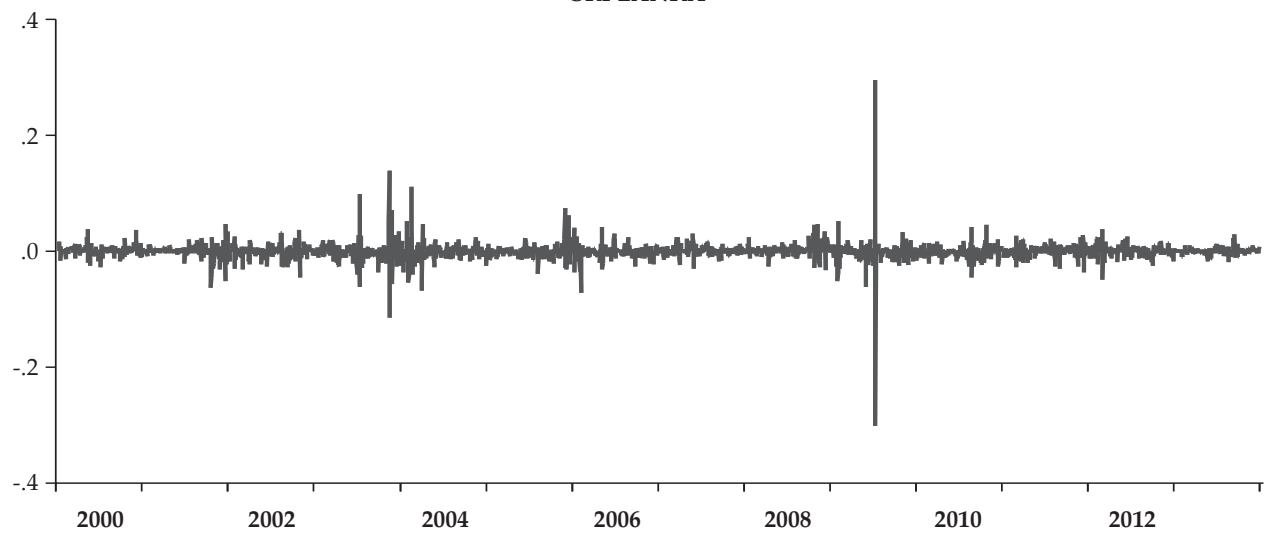

THAILAND

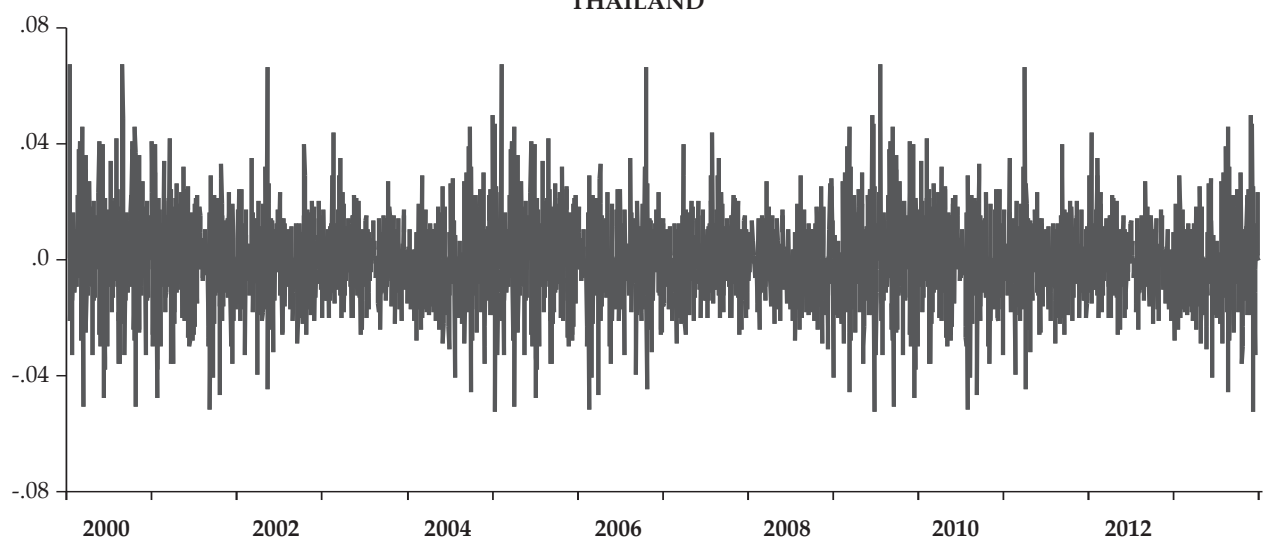

Figure 1.

Returns of Ten Emerging and Frontier Markets

Monthly returns for the emerging and frontier Asian markets are reported in the figure from 2000-2013. (Continued) 
Table 1 provides some common statistics on the daily returns. Over the fourteen years, the Bangladesh stock market executed the highest mean daily return, while Thailand delivered the lowest. None of the dates corresponding to the maximum or minimum values were the same for any of the stock markets, implying that extreme daily movements did not coincide. Standard deviation of all the Asian returns is below 0.01 . The only exception is the Bangladesh stock market which exhibits a deviation of 0.02 . The returns series are negatively skewed in the case of Bangladesh, Malaysia, and Philippines while returns of other countries show positive skewness. The coefficient of kurtosis implies leptokurtic distribution for all the markets.

The pairwise unconditional correlations over the period 2000-2013 are significant for most of the cases (Table 1, panel B). Among other pairs, India's MSCI returns exhibit high correlation with those of Indonesia, Korea, and Malaysia but for the others, low correlation values imply short-term diversification opportunities. Thailand exhibit insignificant correlation with all markets, except for the Korean MSCI.

Table 1.

Descriptive Properties for Daily Return Series

\begin{tabular}{|c|c|c|c|c|c|c|c|c|c|c|}
\hline Variables & Bangladesh & China & India & Indonesia & Korea & Malaysia & Pakistan & Philippines & Sri Lanka & Thailand \\
\hline \multicolumn{11}{|c|}{ Panel A: Descriptive Statistics } \\
\hline Mean & 0.0048 & 0.0001 & -0.0001 & -0.0003 & 0.0000 & -0.0001 & -0.0005 & 0.0001 & -0.0006 & 0.0000 \\
\hline Max. & 0.0980 & 0.0930 & 0.1180 & 0.1100 & 0.1280 & 0.1920 & 0.0770 & 0.1618 & 0.2970 & 0.0680 \\
\hline Corresponding date & 11.01.11 & 02.26 .07 & 05.14.04 & 10.07 .08 & 09.11 .01 & 01.19 .10 & 05.17.02 & 01.22 .01 & 06.25 .09 & 01.25 .05 \\
\hline Min. & -0.0980 & -0.0900 & -0.1600 & -0.0760 & -0.1130 & -0.1990 & -0.0830 & -0.1309 & -0.3050 & -0.0540 \\
\hline Corresponding date & 06.29.11 & 10.22 .01 & 05.15 .09 & 01.22 .08 & 10.29 .08 & 01.20 .10 & 06.23 .08 & 10.27 .08 & 06.26 .09 & 12.30 .04 \\
\hline Std. dev. & 0.0217 & 0.0153 & 0.0156 & 0.0139 & 0.0163 & 0.0100 & 0.0134 & 0.0134 & 0.0135 & 0.0150 \\
\hline Skew. & -0.0526 & 0.1791 & 0.1772 & 0.7040 & 0.6512 & -0.8369 & 0.3172 & -0.0969 & 0.1436 & 0.2127 \\
\hline Kurt. & 7.8640 & 7.5435 & 10.7886 & 9.7273 & 9.2360 & 115.3645 & 6.6048 & 14.7322 & 163.8707 & 4.7916 \\
\hline \multicolumn{11}{|l|}{ Panel B: Correlations } \\
\hline Bangladesh & 1 & 0.0214 & $-0.0344^{*}$ & -0.0280 & $-0.0698^{*}$ & -0.0263 & 0.0161 & -0.0011 & $-0.0430^{*}$ & 0.0264 \\
\hline China & & 1 & $0.1669^{*}$ & $0.1777^{*}$ & $0.1841^{*}$ & $0.1651^{*}$ & $0.0476^{*}$ & 0.0124 & 0.0136 & 0.0187 \\
\hline India & & & 1 & $0.3571^{*}$ & $0.3564^{*}$ & $0.2215^{*}$ & $0.0855^{*}$ & $-0.0325^{*}$ & 0.0273 & 0.0030 \\
\hline Indonesia & & & & 1.0000 & $0.3800^{*}$ & $0.3294^{*}$ & $0.0936^{*}$ & $-0.0490^{*}$ & $0.048^{*}$ & -0.0040 \\
\hline Korea & & & & & 1 & $0.3210^{*}$ & $0.0695^{*}$ & -0.0171 & $0.0444^{*}$ & $0.0339^{*}$ \\
\hline Malaysia & & & & & & 1 & $0.0766^{*}$ & $-0.0501^{*}$ & 0.0219 & 0.0064 \\
\hline Pakistan & & & & & & & 1 & -0.0291 & 0.0217 & -0.0264 \\
\hline Philippines & & & & & & & & 1 & -0.0011 & 0.0078 \\
\hline Sri Lanka & & & & & & & & & 1 & 0.0085 \\
\hline Thailand & & & & & & & & & & 1 \\
\hline
\end{tabular}


Panel A of this table displays the common statistics for daily MSCI returns of ten Asian countries over the period 2000-2013. Panel B presents the unconditional correlations among MSCI returns of the Asian countries. * denotes level of significance at 5 percent or better.

Next, the panel ADF unit root tests suggests stationarity of the MSCI indices (excluding one country at a time in returns form (Table 2). These results are further confirmed by two other commonly applied panel unit root tests, Im, Pesaran and Shin (IPS, 2003) and Levin, Lin and Chu (LLC, 2002).

Table 2.

Panel Unit Root Test Results

\begin{tabular}{lccccccc}
\hline & \multicolumn{2}{c}{$\begin{array}{c}\text { ADF Statistics } \\
\text { At Levels }\end{array}$} & $\begin{array}{c}\text { ADF Statistics } \\
\text { 1st Difference }\end{array}$ & $\begin{array}{c}\text { IPS Statistics } \\
\text { At Levels }\end{array}$ & $\begin{array}{c}\text { IPS Statistics } \\
\text { 1st }\end{array}$ & $\begin{array}{c}\text { Lifference } \\
\text { At Levels }\end{array}$ & $\begin{array}{c}\text { LLC Statistics } \\
1^{\text {st }} \text { Difference }\end{array}$ \\
\hline Panel A excluding Bangladesh & 15.9298 & $491.306^{*}$ & -17.2057 & $-74.6381^{*}$ & -1.5251 & $136.693^{*}$ \\
Panel B excluding China & 38.5234 & $1475.77^{*}$ & -14.0044 & $-79.9007^{*}$ & -0.2457 & $58.3201^{*}$ \\
Panel C excluding India & 10.2899 & $888.973^{*}$ & -3.9005 & $-79.5178^{*}$ & -0.8306 & $66.153^{*}$ \\
Panel D excluding Indonesia & 9.6028 & $850.855^{*}$ & -3.8706 & $-79.4992^{*}$ & -1.2118 & $56.4005^{*}$ \\
Panel E excluding Korea & 16.2050 & $1516.43^{*}$ & -3.7248 & $-79.7908^{*}$ & -1.0283 & $67.6959^{*}$ \\
Panel F excluding Malaysia & 12.7977 & $1192.78^{*}$ & -3.8141 & -79.8693 & -1.4955 & $55.1019^{*}$ \\
Panel G excluding Pakistan & 36.6636 & $726.083^{*}$ & -14.9084 & $-69.0273^{*}$ & 147.991 & $3286.60^{*}$ \\
Panel H excluding Philippine & 12.7977 & $1192.78^{*}$ & -4.0867 & $-80.8901^{*}$ & -1.4204 & $53.9834^{*}$ \\
Panel I excluding Sri Lanka & 9.9572 & $842.694^{*}$ & -3.4974 & $-79.7301^{*}$ & -0.7376 & $61.3262^{*}$ \\
Panel J excluding Thailand & 18.1155 & $664.201^{*}$ & -3.3243 & $-77.7970^{*}$ & -0.8773 & $74.3484^{*}$ \\
\hline
\end{tabular}

This table presents the panel ADF, IPS, and LLC test results for the EFA portfolios (country js) excluding one country at a time. The tests are conducted with a drift and no trend for the levels and returns of MSCI indices.

Table 3, which displays panel Granger causality test results, sheds more light on the relationship between a single Asian stock market against a portfolio of nine other Asian stock markets. Here we examine whether each of the ten MSCI returns Granger causes the rest of the returns in the panel and vice versa, following Dumitrescu \& Hurlin (2012) which allows all coefficients to be different across the cross-sections. We find that the results overwhelmingly point to a bidirectional link between one of the ten nation's MSCI returns and the other nine MSCI returns portfolio. This finding supports our development of the portfolios. 
Table 3.

Panel Causality Tests

\begin{tabular}{lccc}
\hline \multicolumn{1}{c}{ Direction of Causality } & \multicolumn{3}{c}{ EFA Panel } \\
\cline { 2 - 4 } & $W_{N, T}^{H N C}$ & $Z_{N, T}^{H N C}$ & P-Value \\
\hline Bangladesh $\rightarrow$ Country js & 4.61389 & 3.91486 & 0.000 \\
Country js $\rightarrow$ Bangladesh & 89.6253 & 131.291 & 0.000 \\
China $\rightarrow$ Country js & 7.76641 & 8.63843 & 0.000 \\
Country js $\rightarrow$ China & 8.81082 & 10.2033 & 0.000 \\
India $\rightarrow$ Country js & 70.3119 & 102.353 & 0.000 \\
Country js $\rightarrow$ India & 14.7253 & 19.0653 & 0.000 \\
Indonesia $\rightarrow$ Country js & 22.5038 & 30.7201 & 0.000 \\
Country js $\rightarrow$ Indonesia & 68.9182 & 100.265 & 0.000 \\
Korea $\rightarrow$ Country js & 21.1862 & 28.746 & 0.000 \\
Country js $\rightarrow$ Korea & 21.7299 & 29.561 & 0.000 \\
Malaysia $\rightarrow$ Country js & 38.8092 & 55.1512 & 0.000 \\
Country js $\rightarrow$ Malaysia & 20.0118 & 26.9862 & 0.000 \\
Pakistan $\rightarrow$ Country js & 40.3835 & 57.5101 & 0.000 \\
Country js $\rightarrow$ Pakistan & 24.3949 & 33.5537 & 0.000 \\
Philippines $\rightarrow$ Country js & 15.5106 & 20.2420 & 0.000 \\
Country js $\rightarrow$ Philippine & 31.7892 & 44.6329 & 0.000 \\
Srilanka $\rightarrow$ Country js & 53.8444 & 77.6792 & 0.000 \\
Country js $\rightarrow$ Srilanka & 17.7773 & 23.6382 & 0.000 \\
Thailand $\rightarrow$ Country js & 24.9953 & 34.4533 & 0.000 \\
Country js $\rightarrow$ Thailand & 92.3677 & 135.401 & 0.000 \\
\hline
\end{tabular}

For Granger causality we have used technique proposed by DumitrescuHurlin (2012), allowing all coefficients to be different across cross-sections. Panel causality test is run between ten Asian countries - each time we take returns of a single country vs a panel of nine Asian countries' returns, excluding that single country. The equation for this panel causality is presented as $P_{i t}=\alpha_{i}+\sum_{m=1}^{M} \gamma_{i}^{(m)} P_{i, t-m}+\sum_{m=1}^{M} \beta_{i}^{(m)} P_{j, t-k}+\varepsilon_{i t}$. Here, $P_{i t}$ is each of the ten Asian nations' MSCI; $P_{j t}$ is a portfolio of MSCI of other nine nations. Null hypothesis states no causal relationship for any cross section panels, i.e. Homogeneous NonCausality hypothesis (HNC). We assume that $\beta_{i}$ varies across cross sections. In the table presented below, $W_{N, T}^{H N C}$ is the average statistics related to Homogeneous NonCausality hypothesis (HNC). $Z_{N, T}^{H N C}$ is the standardized test statistic converging to chi-square distribution with $\mathrm{M}$ degrees of freedom. Lag length is 2 and selected as per Akaike Information Criteria (AIC). 
However, our variance decomposition analyses that use unrestricted VAR suggest that each of the nations is minimally affected by the rest of the nine Asian nations (see Table 4). For India, Korea, and Malaysia, the percentage of the variation in their returns explained by the rest of the nine Asian countries range from 0 to $1 \%$; and from 0 to less than $0.5 \%$ for each of the other nations. For each of the ten nations, the nine-Asian country panel begins to matter from the second year and explains the variance more over time.

Table 4.

Forecast Error Variance Decomposition Test

\begin{tabular}{lcccccccccc}
\hline \multicolumn{1}{c}{ Country } & $\mathbf{1}$ & $\mathbf{2}$ & $\mathbf{3}$ & $\mathbf{4}$ & $\mathbf{5}$ & $\mathbf{6}$ & $\mathbf{7}$ & $\mathbf{8}$ & $\mathbf{9}$ & $\mathbf{1 0}$ \\
\hline Bangladesh & 0.0000 & 0.0154 & 0.0147 & 0.0221 & 0.0268 & 0.0338 & 0.0407 & 0.0486 & 0.0569 & 0.0658 \\
China & 0.0000 & 0.0186 & 0.0282 & 0.0481 & 0.0698 & 0.0968 & 0.1271 & 0.1612 & 0.1983 & 0.2383 \\
India & 0.0000 & 0.4774 & 0.3855 & 0.5463 & 0.5768 & 0.6796 & 0.7571 & 0.8561 & 0.9529 & 1.0576 \\
Indonesia & 0.0000 & 0.0000 & 0.0160 & 0.0298 & 0.0587 & 0.0919 & 0.1351 & 0.1845 & 0.2413 & 0.3042 \\
Korea & 0.0000 & 0.0348 & 0.0773 & 0.1549 & 0.2496 & 0.3683 & 0.5044 & 0.6578 & 0.8247 & 1.0033 \\
Malaysia & 0.0000 & 0.0478 & 0.1005 & 0.1981 & 0.3137 & 0.4564 & 0.6158 & 0.7909 & 0.9765 & 1.1694 \\
Pakistan & 0.0000 & 0.0019 & 0.0064 & 0.0087 & 0.0103 & 0.0113 & 0.0121 & 0.0127 & 0.0132 & 0.0136 \\
Philippines & 0.0000 & 0.0004 & 0.0217 & 0.0377 & 0.0762 & 0.1199 & 0.1777 & 0.2440 & 0.3202 & 0.4043 \\
Sri Lanka & 0.0000 & 0.0471 & 0.0518 & 0.0953 & 0.1275 & 0.1773 & 0.2282 & 0.2883 & 0.3525 & 0.4227 \\
Thailand & 0.0000 & 0.0094 & 0.0219 & 0.0440 & 0.0714 & 0.1059 & 0.1458 & 0.1915 & 0.2423 & 0.2979 \\
\hline
\end{tabular}

This table highlights percent contribution of the panel of nine countries stock prices in the single country equity prices not included in that panel. The numbers $1 \rightarrow 10$ represent time horizon for variance decomposition and ranges from 1 to 10 years' period. The forecast error variance decomposition is based on the structural VAR model equation of which is $P_{i t}=v+A_{1} p_{j t-1}+\cdots+A_{p} p_{j t-p}+u_{i t} . P_{i t}$ is each of the ten Asian nations' MSCI; $P_{j t}$ is a portfolio of MSCI of other nine nations, $j$ s. Standard errors for this decomposition analysis are generated using recursive-design wild bootstrap.

\section{PANEL COINTEGRATION TEST}

We begin our empirical analysis for a typical investor in any one of the EFA nations, $i$, with an investment portfolio comprising of their own national stock market index, nine other EFA market indices, and a developed market index (S\&P 500). Of interest to this paper is the following long run relationship for the portfolio conditioned by global sentiments and oil price movements:

$$
P_{i t}=\delta_{1 i}+\theta_{1 i} P_{j t}+\theta_{2 i} S \& P 500_{i t}+\theta_{3 i} \text { senti }_{i t}+\theta_{4 i} \text { Brent }_{i t}+\mu_{i t}
$$


$S \mathcal{E} P 500_{i t}$ captures the US market movements, which is commonly found to have a substantial effect on Asian markets (also see Narayan et al., 2014; Narayan and Rehman, 2017; Singh et al., 2010; Yang et al., 2003). Brent oil, which is also an indicator of economic activity, is seen as an important determinant of Asian returns by previous studies (see Abdullah et al., 2016; Lin et al., 2014; Narayan \& Narayan, 2010). We source this data from the Thomson Reuters Data Stream Financials. Investor sentiment is included as part of explaining changes in stock returns, following the irrational asset pricing models of Lee et al. (1991) and De Long et al. (1990) that focus on sentiment-driven factors. Only a few studies show that global, as well as local, investor sentiment has a reasonable level of influence on return-sensitive stocks in emerging markets (see Baker et al, 2012; Chang, et al., 2012).

Three different cointegration tests, namely the Kao (1999), Maddala \& Wu (1999) and Pedroni $(1999,2004)$ tests, were performed to check for the presence of a cointegrating relationship in this portfolio or the relationship depicted in equation (1). ${ }^{5}$ Cointegration test results displayed in Table 5 imply the presence of more than one long-run cointegrating relationship among the variables in equation (1).

Table 5.

Cointegration Test Results

\begin{tabular}{|c|c|c|c|c|c|c|c|c|c|c|c|c|c|}
\hline & \multirow{2}{*}{$\begin{array}{c}\begin{array}{c}\text { Kao Panel } \\
\text { Cointegration }\end{array} \\
\text { ADF t-Stat. }\end{array}$} & \multicolumn{7}{|c|}{ Pedroni Panel Co-integration Statistics } & \multicolumn{5}{|c|}{$\begin{array}{c}\text { Johansen Panel Co-integration } \\
\text { Trace statistics }\end{array}$} \\
\hline & & Panel v & $\begin{array}{l}\text { Panel } \\
\text { rho }\end{array}$ & $\begin{array}{l}\text { Panel } \\
\text { PP }\end{array}$ & $\begin{array}{l}\text { Panel } \\
\text { ADF }\end{array}$ & $\begin{array}{l}\text { Group } \\
\text { rho }\end{array}$ & $\begin{array}{l}\text { Group } \\
\text { PP }\end{array}$ & $\begin{array}{l}\text { Group } \\
\text { ADF }\end{array}$ & None & 1 & 2 & 3 & 4 \\
\hline Bangladesh & $-3.9055^{*}$ & 0.1872 & 0.2055 & -0.1111 & 0.5157 & 1.3193 & 0.6985 & 0.2417 & 0.000 & $103.1^{*}$ & $142.9^{*}$ & 12.94 & $30.86^{* *}$ \\
\hline China & $-43.6289^{*}$ & 0.7627 & $-1016.087^{*}$ & $-199.4247^{*}$ & $-140.0279^{*}$ & $-1048.337^{\star}$ & $-223.6433^{*}$ & $-156.7950^{*}$ & 0.000 & $84.72^{*}$ & $151.7^{*}$ & 12.61 & $28.05^{* *}$ \\
\hline India & $-3.6992^{*}$ & 0.0777 & 0.3848 & 0.2082 & -0.1976 & 1.5031 & 1.0674 & 0.6092 & 0.000 & $47.91^{*}$ & $86.42^{*}$ & $12.64^{*}$ & $27.90^{* *}$ \\
\hline Indonesia & $-34.3654^{*}$ & 0.7299 & $-1011.574^{*}$ & $-199.4879^{*}$ & $-139.9861^{*}$ & $-1043.553^{*}$ & $-223.7291^{*}$ & $-156.74399^{*}$ & 0.000 & $66.30^{*}$ & $160.2^{*}$ & 12.62 & $28.08^{* *}$ \\
\hline Korea & $-33.3175^{*}$ & 0.5358 & $-1013.692^{*}$ & $-199.4136^{*}$ & $-140.0111^{*}$ & $-1045.848^{*}$ & $-223.6262^{*}$ & $-156.7755^{*}$ & 0.000 & $47.95^{*}$ & $86.60^{*}$ & 12.61 & $29.14^{*}$ \\
\hline Malaysia & $-17.8851^{*}$ & 0.4782 & $-1009.921^{*}$ & $-199.4655^{*}$ & $-140.0695^{*}$ & $-1041.872^{*}$ & $-223.6976^{*}$ & $-156.8430^{*}$ & 0.000 & 0.000 & $110.7^{*}$ & 14.09 & $31.26^{*}$ \\
\hline Pakistan & $-20.9901^{*}$ & -167.9604 & $-266.1105^{*}$ & $-53.0745^{*}$ & $-20.2547^{*}$ & $-1158.078^{*}$ & $-163.4860^{*}$ & -54.7393 & 0.000 & $36.84^{*}$ & $160.4^{*}$ & 21.60 & $27.77^{* *}$ \\
\hline Philippine & $-22.8735^{*}$ & 0.6385 & $-1013.252^{*}$ & $-200.1338^{*}$ & $-140.3730^{*}$ & $-1045.453^{*}$ & $-224,4929^{*}$ & $-157.2014^{*}$ & 0.000 & $48.14^{*}$ & $86.64^{*}$ & 12.79 & $30.41^{*}$ \\
\hline Sri Lanka & $-50.2625^{*}$ & 0.6834 & $-1013.788^{*}$ & $-199.7895^{*}$ & $-140.2216^{*}$ & $-1045.915^{*}$ & $-224.0783^{*}$ & $-157.0193^{*}$ & 0.000 & $47.87^{*}$ & $86.80^{*}$ & 12.58 & $28.18^{* *}$ \\
\hline Thailand & $-26.4190^{*}$ & 0.6718 & $-1016.675^{*}$ & $-199.4258^{*}$ & $-140.0453^{*}$ & $-1048.937^{\star}$ & $-223.6407^{*}$ & $-156.8147^{*}$ & 0.000 & $121.8^{*}$ & $241.3^{*}$ & 13.09 & $31.08^{*}$ \\
\hline
\end{tabular}

5 For discussion on the differences between the techniques see Narayan and Nguyen (2014); Narayan and Smyth (2015) 
This table presents results from three cointegration tests, namely Kao (1999), Maddala and Wu (1999), and Pedroni (1999, 2004). of interest is the long-run relationshipdepictedinequation(1): $P_{i t}=\delta_{1 i}+\theta_{1 i} P_{i t}+\theta_{2 i} S \mathcal{E} P 500_{i t}+\theta_{3 i}$ senti $_{i t}+\theta_{4 i}$ Brent $_{i t}+\mu_{i t}$. Here, $P_{i t}$ is each of the ten Asian nations' MSCI; $P_{j t}$ is a portfolio of MSCI of other nine nations; senti $i_{i t}$ are global investor sentiments; Brent ${ }_{i t}$ is Brent oil price series; and $S \mathcal{E} P 500_{i t}$ is the price index to the US market. ${ }^{*}$ denotes significance at 5 percent or better.

\section{VECTOR ERROR CORRECTION MODEL (VECM)}

Here, we estimate the short-run relationship between the variables using the panel VECM model. Of interest is the relationship portrayed here in equation (2):

$$
\begin{aligned}
& \Delta P_{i t}=\delta_{2 i}+\theta_{1 i} \sum_{k=1}^{n} \Delta P_{j t-k}+\theta_{2 i} \sum_{k=1}^{n} \Delta B R E N T_{i t-k}+\theta \sum_{3 i}^{n} \Delta S_{k=1}^{n} \operatorname{SNTI}_{2, i t-k} \\
& +\theta_{3 i} \sum_{k=1}^{n} \Delta S \& P 500_{i t-k}+\delta_{1 i} E C T_{i t-1}+\epsilon_{i t}
\end{aligned}
$$

All variables from equation (1) appear in equation (2) in first differenced form, represented by $\Delta$. The parameters to be estimated are $\delta$ and $\theta s$. The Error Correction Term (ECT), which is one lag of the residual from equation (1) if significant and negative, confirms a stable long-run relationship between the variables identified. The ECT is only significant for returns of India, Korea, Malaysia, Pakistan, the Philippines, and Thailand as the dependent variable. This suggests that a stable long-run relationship between returns of countries $i$ and $j$ exists for these six countries. However, this is not so for the returns of Bangladesh, China, Indonesia, and Sri Lanka, suggesting that the long-term investment opportunities in other EFA nations including the S\&P 500 may be stronger for the four nations than for other nations (India, Korea, Malaysia, Pakistan, the Philippines, and Thailand).

Evidence of any short-run linkage between returns of country $i$ and $j$ s, is rather scant. Only in the case of Korea, Malaysia, and Pakistan do we notice a significant short-term link with the returns of the other Asian nations (or country js) (Table 6). These results imply that short-term gains are limited for the three nations investing in the other EFA markets compared to other Asian nations investing in the EFA markets.

No other variable show a significant link, except S\&P 500 returns for Malaysian returns. Our results thus far suggest stable long-run relationship expressed in equation (1) for same EFA nations but rather limited short-run correlations between any one of the ten Asian countries and the other the nine Asian nations' returns. The link between the EFA nations and S\&P 500 is also lacking. 
Table 6.

VECM Results

\begin{tabular}{|c|c|c|c|c|c|c|c|c|c|c|}
\hline Regressors & Intercept & $\begin{array}{c}\text { Portfolio } \\
\text { ret (-1) }\end{array}$ & $\begin{array}{l}\text { Portfolio } \\
\text { ret (-2) }\end{array}$ & $\begin{array}{l}\Delta \text { Brent } \\
\text { Oil (-1) }\end{array}$ & $\begin{array}{c}\Delta \text { Brent } \\
\text { Oil } \\
(-2)\end{array}$ & $\begin{array}{l}\Delta \text { Sent. } \\
(-1)\end{array}$ & $\begin{array}{l}\Delta \text { Sent. } \\
(-2)\end{array}$ & $\begin{array}{c}\Delta \mathrm{SP} 500 \\
(-1)\end{array}$ & $\begin{array}{c}\Delta S P 500 \\
(-2)\end{array}$ & ECT (-1) \\
\hline \multirow[t]{2}{*}{ Bangladesh } & 0.2482 & 0.0007 & 0.0015 & -0.0051 & -0.0070 & 1.2275 & 5.2269 & -0.0013 & -0.0016 & -0.0003 \\
\hline & $(0.2478)$ & $(0.1233)$ & $(0.1233)$ & $(0.2036)$ & $(0.2032)$ & $(72.8270)$ & $(72.7879)$ & $(0.1516)$ & $(0.1516)$ & $(0.0020)$ \\
\hline \multirow[t]{2}{*}{ China } & 0.0684 & 0.0684 & 0.0684 & 0.0684 & 0.0684 & 0.0684 & 0.0684 & 0.0684 & 0.0684 & 0.0684 \\
\hline & $(0.0683)$ & $(0.0353)$ & $(0.0353)$ & $(0.0561)$ & $(0.0560)$ & $(20.0636)$ & $(20.0528)$ & $(0.0418)$ & $(0.0418)$ & $(0.0020)$ \\
\hline \multirow[t]{2}{*}{ India } & 0.6533 & -0.0955 & -0.1108 & -0.0211 & -0.0218 & 1.8952 & 15.2825 & -0.0179 & -0.0088 & $0.0040^{*}$ \\
\hline & $(0.6282)$ & $(0.3432)$ & (0.3432) & $(0.5162)$ & $(0.5153)$ & (184.6449) & (184.5462) & $(0.3844)$ & $(0.3844)$ & $(0.0019)$ \\
\hline \multirow[t]{2}{*}{ Indonesia } & 0.1314 & -0.0705 & -0.0434 & -0.0120 & -0.0103 & 7.1910 & -3.8089 & -0.0141 & -0.0055 & 0.0004 \\
\hline & (0.1299) & $(0.0685)$ & $(0.0685)$ & $(0.1067)$ & $(0.1065)$ & (38.1728) & (38.1522) & $(0.0795)$ & $(0.0795)$ & $(0.0020)$ \\
\hline \multirow[t]{2}{*}{ Korea } & 0.0603 & $-0.0819^{*}$ & -0.0402 & 0.0078 & -0.0001 & 0.8241 & 0.9215 & 0.0017 & -0.0205 & $-0.0057^{*}$ \\
\hline & $(0.0634)$ & $(0.0331)$ & $(0.0331)$ & $(0.0521)$ & $(0.0520)$ & (18.6289) & (18.6188) & $(0.0388)$ & $(0.0388)$ & $(0.0020)$ \\
\hline \multirow[t]{2}{*}{ Malaysia } & -0.0003 & $-0.0176^{*}$ & -0.0075 & 0.0115 & 0.0081 & 2.8134 & -3.2628 & $-0.0141^{*}$ & -0.0076 & $-0.8037^{*}$ \\
\hline & $(0.0088)$ & $(0.0046)$ & $(0.0046)$ & $(0.0072)$ & $(0.0072)$ & (2.5805) & $(2.5791)$ & $(0.0054)$ & $(0.0054)$ & $(0.0056)$ \\
\hline \multirow[t]{2}{*}{ Pakistan } & 0.7677 & $0.0114^{*}$ & $0.0114^{*}$ & -0.0115 & -0.0328 & 10.5469 & 9.2368 & -0.0151 & -0.0179 & $0.0058^{*}$ \\
\hline & $(0.7433)$ & $(0.0065)$ & $(0.0059)$ & $(0.6107)$ & $(0.6097)$ & (218.4636) & (218.3466) & $(0.4547)$ & $(0.4548)$ & $(0.0034)$ \\
\hline \multirow[t]{2}{*}{ Philippine } & 0.1785 & 0.1785 & 0.1785 & 0.1785 & 0.1785 & 0.1785 & 0.1785 & 0.1785 & 0.1785 & $0.1785^{*}$ \\
\hline & $(0.1890)$ & $(0.1007)$ & (0.1008) & $(0.1553)$ & $(0.1550)$ & (55.5395) & (55.5095) & $(0.1156)$ & $(0.1156)$ & $(0.0020)$ \\
\hline \multirow[t]{2}{*}{ Sri Lanka } & 0.1773 & -0.0842 & -0.0593 & 0.0056 & -0.0341 & -2.2664 & 6.8962 & -0.0276 & -0.0150 & -0.0002 \\
\hline & $(0.1764)$ & $(0.0965)$ & $(0.0965)$ & $(0.1449)$ & $(0.1447)$ & $(51.8461)$ & $(51.8183)$ & $(0.1079)$ & $(0.1079)$ & $(0.0020)$ \\
\hline \multirow[t]{2}{*}{ Thailand } & -0.0006 & 0.0000 & 0.0000 & 0.0045 & 0.0003 & 1.3541 & -1.3820 & 0.0015 & 0.0018 & $-0.1389^{*}$ \\
\hline & $(0.0057)$ & $(0.0002)$ & $(0.0002)$ & $(0.0047)$ & $(0.0047)$ & (1.6737) & (1.6728) & $(0.0035)$ & $(0.0035)$ & $(0.0028)$ \\
\hline
\end{tabular}

The table presents the VECM model (2): $\Delta P_{i t}=\delta_{2 i}+\theta_{1 \mathrm{i}} \sum_{k=1}^{n} \Delta P_{j t-k}+\theta_{2 i} \sum_{k=1}^{n}$ $\triangle B R E N T_{i t-k}+\theta_{3 i} \sum_{k=1}^{n} \Delta S E N T I_{2, i t-k}+\theta_{3 i} \sum_{k=1}^{n} \Delta S \mathcal{E} P 500_{i t-k}+\delta_{1 i} E C T_{i t-1}+\epsilon_{i t}$. Here, $\Delta P_{i t}$ is each of the ten Asian nations' MSCI returns; $\Delta P_{j t}$ is a portfolio of MSCI returns of other nine nations; senti $i_{i t}$ are global investor sentiments; Brent $t_{i t}$ is Brent oil price series; and $S \mathcal{E} P 500_{i t}$ is the price index to the US market. These variables appear in first differenced form, represented by $\Delta, \delta$, and $\theta s$ are the parameters to be estimated. The Error Correction Term (ECT) which is one lag of the residual from equation (1), if significant and negative, confirms a stable long-run relationship between the variables identified. Values in parenthesis are standard errors. ${ }^{*}$ denotes level of significance at 5 percent or better. 


\section{LONG-RUN REGRESSION RESULTS}

We have established two things thus far: (1) that there exists a stable long-run relationship between the returns of six out of the ten Asian nations and the rest of the Asian nations (js); and (2) that the short-run linkages are only present between three out of ten EFA nations and the rest of the Asian nations. Significant short-term and stable long-run relationships between the EFA nations are signs of diminished diversification gains from EFA based investment portfolios. We have found that from EFA based portfolios, long-term portfolio gains are likely to be higher for Bangladesh, China, Indonesia, and Sri Lanka and short-term portfolio are likely to be higher for compared to the other EFAs, India, the Philippines, Thailand, Bangladesh, China, Indonesia, and Sri Lanka. Our short-term finding for Sri Lanka is consistent with Srinanthakumar \& Narayan (2015) who find limited conditional correlations between Sri Lanka and the neighboring countries.

Next we look closely at the long-run linkages between the variables by estimating equation (1) using the Dynamic OLS (DOLS) method. ${ }^{6}$ For this analysis we excluded the four nations that did not show a significant ECT (Bangladesh, China, Indonesia, and Sri Lanka) (see Table 6). For each of the remaining six Asian countries in the first column, the long-run coefficients for the portfolio of returns of country js, or the other nine Asian countries, are displayed in Columns 2 and 3 (Table 7). Note that the long-run results point to a significant and positive link between most of the individual Asian nations and the portfolio of nine nations' returns. The only exception is Thailand, showing no significant long-run correlation with the other nine Asian countries' stock markets. Other variables, except the S\&P 500 , are significant determinants of individual EFA (country i) returns, although EFA returns are almost always more important. Brent is a significant determinant of returns of all six EFA markets examined while global investor sentiments are found to influence returns of Korea, Malaysia, and Thailand.

Table 7.

Long-Run Regression Results

\begin{tabular}{lcccccccc}
\hline & \multicolumn{2}{c}{$\boldsymbol{P}_{i t}$} & \multicolumn{2}{c}{ Brent } & Sentiments & \multicolumn{2}{c}{ SP500 } \\
\hline DOLS Results & & & & & & & & \\
\hline India & $0.2583^{*}$ & 2.7464 & $0.0109^{*}$ & 2.8466 & -0.1574 & -0.7689 & 0.0284 & 0.1645 \\
& -0.0941 & & -0.0038 & & -0.2047 & & -0.1727 & \\
\multirow{2}{*}{ Korea } & $0.1598^{*}$ & 13.0749 & $0.0087^{*}$ & 16.1053 & $-0.1596^{*}$ & -5.4673 & -0.0143 & -0.5806 \\
& -0.0122 & & -0.0005 & & -0.0292 & & -0.0247 & \\
Malaysia & $0.1489^{*}$ & 21.6087 & $0.0062^{*}$ & 18.1076 & $-0.1016^{*}$ & -5.4637 & 0.0098 & 0.6203 \\
& -0.0069 & & -0.0003 & & -0.0186 & & -0.0158 & \\
Pakistan & $2.5506^{*}$ & 74.6252 & $-0.0387^{*}$ & -18.0649 & -0.1005 & -0.8672 & -0.0134 & -0.1356 \\
& -0.0342 & & -0.0021 & & -0.1159 & & -0.0985 & \\
\multirow{2}{*}{ Philippine } & $0.1991^{*}$ & 6.7064 & $0.0098^{*}$ & 7.9867 & 0.0213 & 0.3215 & 0.0185 & 0.3322 \\
& -0.0297 & & -0.0012 & & -0.0662 & & -0.0558 & \\
\multirow{2}{*}{ Thailand } & 0.0001 & 0.0176 & $-0.0500^{*}$ & -51.9761 & $0.9014^{*}$ & 17.1735 & 0.0348 & 0.7768 \\
& -0.0003 & & -0.001 & & -0.0525 & & -0.0448 & \\
\hline
\end{tabular}


This table displays the long-run relationships depicted in equation (1): $P_{i t}=\delta_{1 i}{ }^{+}$ $\theta_{1 i} P_{i t}+\theta_{2 i} S \mathcal{E} P 500_{i t}+\theta_{3 i}$ senti $_{i t}+\theta_{4 i}$ Brent $_{i t}+\mu_{i t}$. Here, $P_{i t}$ is each of the ten Asian nations' MSCI; $P_{j t}$ is a portfolio of MSCI of other nine nations; sent $i_{i t}$ are global investor sentiments; Brent $t_{i t}$ is Brent oil price series; and $S \mathcal{E} P 500_{i t}$ is the price index to the US market. Note that the long-run estimation only relates to the cointegrated relationships depicted in equation (1). ${ }^{*}$ denotes significance at 5 percent or better. Values in parenthesis are standard errors. $3^{\text {rd }}, 5^{\text {th }}, 7^{\text {th }}$, and $9^{\text {th }}$ column represent corresponding t-values for long-run results.

\section{S\&P 500 AND DEVELOPING STOCK MARKET LINKAGES}

Narayan \& Rehman (N-R, 2017), a study that most resonates us, use the same set of Emerging and Frontier Asian (EFA) nations over the same period as ours. The authors examined the response of all EFA nations (expressed within one panel) to changes in other variables including developed nations' stock markets (including the S\&P 500). Like the present paper, several control variables were imposed. N-R (2015) did not allocate the EFA markets (country js) as being part of the investment portfolio as we did in the present study. The authors found that the S\&P 500 was both a long and short-term predictor of the EFA panel with daily data.

Our finding on the effect of developed market (S\&P 500) is different from N-R (2017). We find that S\&P 500 is not a predictor of most of the EFA markets in the short or long-run. The only exception is the Malaysian stock market returns in the short-run. The disparate findings may be explained one major difference between the two papers. N-R (2017) did not consider the EFA markets as part of the portfolio investment in their study. Hence in their models, they did not have a variable $P_{j t}$ in their model. The present paper includes this variable; hence defined portfolio investment opportunities for each individual EFA country (i) against other EFA nations (js) as well as a developed market, the S\&P 500. In other words, in the present paper we have explored overseas investment opportunities for an investor based in one of the EFA nations and investing in other EFA nations and the S\&P 500.

Taken together, these papers bring to our attention the importance of including both the emerging and developed markets in the portfolio for better diversification gains in the short and long-run.

\section{ACCOUNTING FOR EXCHANGE RATE EFFECTS}

We also estimated models inclusive of exchange rates of the country $i$ against the US dollar on the LHS of the equations examined above. The exchange rate data is sourced from the Thomson Reuters Data Stream Financials. These results, presented in the Appendix (Tables A1-A3) are consistent most times, with exchange rate having an insignificant effect in the short and the long-run. However, some divergences is noticed between the new (with exchange rates) and from above old (without exchange rates) results. First, the stable long-run relationship disappears for India and Pakistan in the latest setting, implying that exchange rate movements require hedging for higher long-run investment opportunities in the two South Asian nations. Second, the short-terms results depicted above continue to hold. 
Malaysia is an exception where the effect of other EFAs, $P_{j t^{\prime}}$ disappears after being conditioned by exchange rate movements. Third, the long-run association between the stock markets of Korea and Thailand and $P_{j t}$ is insignificant with the inclusion of exchange rates.

\section{CONCLUDING REMARKS}

Our study explored the feasibility of portfolio investment within Asia for ten emerging and frontier stock markets over the period 2000 to 2013. We found that the unconditional correlations were significant but weak. Nonetheless, the panel Granger causality test suggests the presence of a bi-directional causal relationship between returns for each of the ten Asian nations (country is) and the nine other nations' (country js) returns.

The long and short-run analyses conditioned to other determinants of Asian returns, such as Brent oil price, global investor sentiments, and S\&P 500 returns, revealed several cases of stable long-run linkages but rare cases of short-run linkages between returns of countries is and $j$.

The long-run relationships between returns of six individual Asian countries and the portfolio of the other nine Asian countries' returns were positive and significant. These long-run effects were actually stronger than other determinants of stock markets, including Brent oil, global sentiments, and the S\&P 500.

In particular, our study suggests that the strongest long and short-term diversification gains for investors in these Asian nations occur if stock market interactions are with Bangladesh, China, Indonesia, and Sri Lanka. Interactions with the other six Asian countries will bring more significant benefits in the shortterm than the long-run.

These results imply that diversification gains within Asia are promising. However, whether these gains are comparable to having a portfolio of developed nations or other emerging and frontier markets is left as part a future research agenda.

\section{REFERENCES}

Abdullah, A. M., Saiti, B., Masih, M., (2016). The impact of crude oil price on Islamic stock indices of South East Asian countries: Evidence from MGARCHDCC and wavelet approaches, Borsa Istanbul Review, 16(4), 219-232

Al Asad Bin Hoque, H. (2007). Co-movement of Bangladesh stock market with other markets: Cointegration and error correction approach. Managerial Finance, 33(10), 810-820.

Auer, B. R. (2016). On time-varying predictability of emerging stock market returns. Emerging Markets Review, 27, 1-13.

Baker, M., Wurgler, J., \& Yuan, Y. (2012). Global, local, and contagious investor sentiment. Journal of Financial Economics, 104(2), 272-287.

Batareddy, M., Gopalaswamy, A. K., Huang, C-H., 2012. The stability of long-run relationships: A study on Asian emerging and developed stock markets (Japan and US), International Journal of Emerging Markets, 7(1), 31-48. 
Chang, S. C., Chen, S. S., Chou, R. K., \& Lin, Y. H. (2012). Local sports sentiment and returns of locally headquartered stocks: A firm-level analysis. Journal of Empirical Finance, 19(3), 309-318.

Chiang, T. C., Jeon, B. N., \& Li, H. (2007). Dynamic correlation analysis of financial contagion: Evidence from Asian markets. Journal of International Money and Finance, 26(7), 1206-1228.

De Long, J. B., Shleifer, A., Summers, L. H., \& Waldmann, R. J. (1990). Noise trader risk in financial markets. Journal of Political Economy, 98(4), 703-738.

Dumitrescu, E. I., \& Hurlin, C. (2012). Testing for Granger non-causality in heterogeneous panels. Economic Modelling, 29(4), 1450-1460.

Jayasuriya, S. A. (2011). Stock market correlations between China and its emerging market neighbors. Emerging Markets Review, 12 (4), 418-431.

Im, K. S., Pesaran, M. H., \& Shin, Y. (2003). Testing for unit roots in heterogeneous panels. Journal of Econometrics, 115(1), 53-74.

Kao, C. (1999). Spurious regression and residual-based tests for cointegration in panel data. Journal of econometrics, 90(1), 1-44.

Kenourgios, D. \& Padhi, P. (2012). Emerging markets and financial crises: regional, global or isolated shocks? Journal of Multinational Financial Management, 22(1), 24-38.

Lee, C., Shleifer, A., \& Thaler, R. H. (1991). Investor sentiment and the closed-end fund puzzle. The Journal of Finance, 46(1), 75-109.

Levin, A., Lin, C.F., \& Chu, C. S. J. (2002). Unit root tests in panel data: asymptotic and finite-sample properties. Journal of Econometrics, 108,1-24.

Lin, C-C., Fang, C-R., \& Cheng, H-P., (2014) The Impact of Oil Price Shocks on the Returns in China's Stock Market, Emerging Markets Finance and Trade, 50(5), 193-205

Maddala, G. S., \& Wu, S. (1999). A comparative study of unit root tests with panel data and a new simple test. Oxford Bulletin of Economics and statistics, 61(S1), 631-652.

Manning, N. (2002). Common trends and convergence? South East Asian equity markets, 1988-1999. Journal of International Money and Finance, 21(2), 183-202.

Mukherjee, P. \& Bose, S. (2008). Does the stock market in India move with Asia? A multivariate cointegration-vector autoregression approach. Emerging Markets Finance and Trade, 44(5), 5-22.

Narayan, P. K. and S. Narayan (2010). Modelling the Impact of Oil Prices on Vietnam's Stock Prices. Applied Energy. 87(1), 356-361.

Narayan, S. (2015). Are Asian stock market returns predictable? Emerging Markets Finance and Trade, 51(5), 867-878,

Narayan, S., \& Nguyen, T.T., (2015). Does the Trade Gravity Model depend on Trading Partners? Some evidence from Vietnam and her 54 trading partners, International Review of Economics and Finance, 41, 220-237.

Narayan, S. \& Smyth, R., (2015), The Financial Econometrics of Price Discovery and Predictability, International Review of Financial Analysis, 42, 380-393.

Narayan, S., \& Rehman, M (2017). Diversification opportunities between the Emerging and Frontier Asian (EFA) and Developed Stock Markets, Finance Research Letters, 23, 223-232. 
Narayan, S., Sriananthakumar, S., Islam, S. Z., (2014) Stock Market Integration Emerging Asian economies: Patterns and causes, Economic Modelling, 39, 19-31.

Pedroni, P. (1999). Critical values for cointegration tests in heterogeneous panels with multiple regressors. Oxford Bulletin of Economics and statistics, 61(S1), 653670.

Pedroni, P. (2004). Panel cointegration: asymptotic and finite sample properties of pooled time series tests with an application to the PPP hypothesis. Econometric theory, 20(3), 597-625.

Phylaktis, K., \& Ravazzolo, F. (2002). Measuring financial and economic integration with equity prices in emerging markets. Journal of International Money and Finance, 21(6), 879-903.

Rehman, M. U. \& Kashif, M. (2018). Commonalities between financial and market integration and equity return co-movements in emerging and frontier markets, AESTIMATIO, The IEB International Journal of Finance, 17, pp. 184-203.

Rehman, M. U., \& Shah, S. M. A. (2016). Does Bilateral Market and Financial Integration Explains International Co-Movement Patterns1. International Journal of Financial Studies, 4(2), 10.

Singh, P., Kumar, B., \& Pandey, A. (2010). Price and volatility spillovers across North American, European and Asian stock markets. International Review of Financial Analysis, 19(1), 55-64.

Sriananthakumar, S., \& Narayan, S., (2015). Are prolonged conflict and tension deterrent for stock market integration? The case of Sri Lanka. International Review of Economics and Finance, 39, 504-520.

Yang, J., Kolari, J. W., \& Min, I. (2003). Stock market integration and financial crises: the case of Asia. Applied Financial Economics, 13(7), 477-486. 


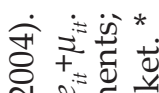

๙

बं है है

वे क्य

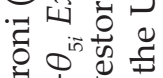

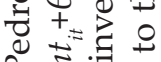

돈

व $0 \frac{2}{60}$.

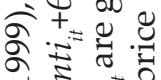

बे

50 का

$3+\neq$ is.?

등 유

ส $\frac{1}{2} \stackrel{1}{2}$

क्षे की की

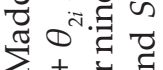

$\sum+ \pm \overline{0}$

बर $=$ 吾

बे 0 능

व

$\underset{\sim}{*}=\sum^{N}$

추융ㅇㅇㅇ

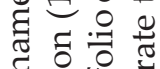

के

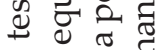

ธี..

-

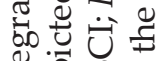

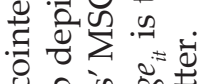

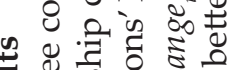

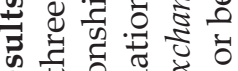

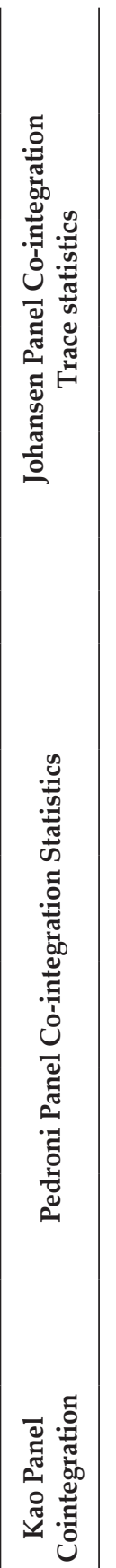

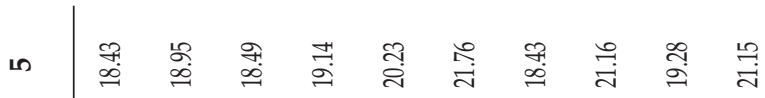

$+\quad$ 菅 品

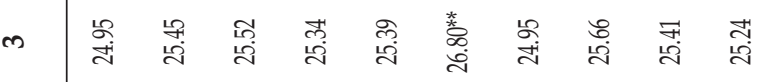

N 苦

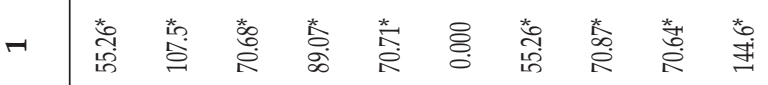

‡゙

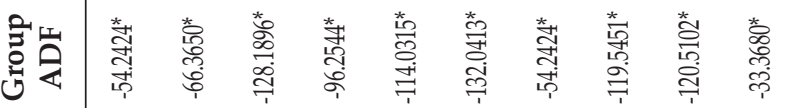

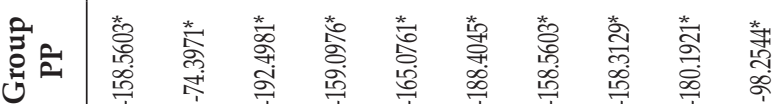

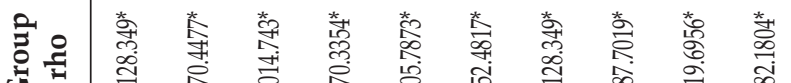

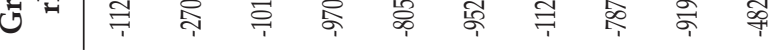

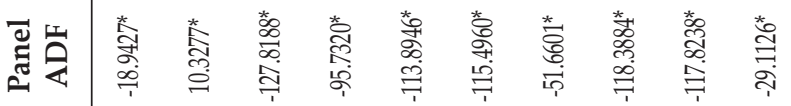

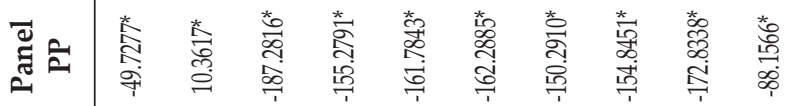

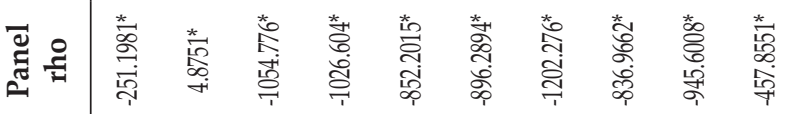

$\simeq \approx$ 幽艺

हृत्त क के

क屯心

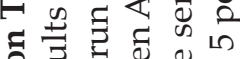

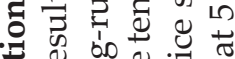

ॠ

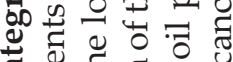

节离至

-

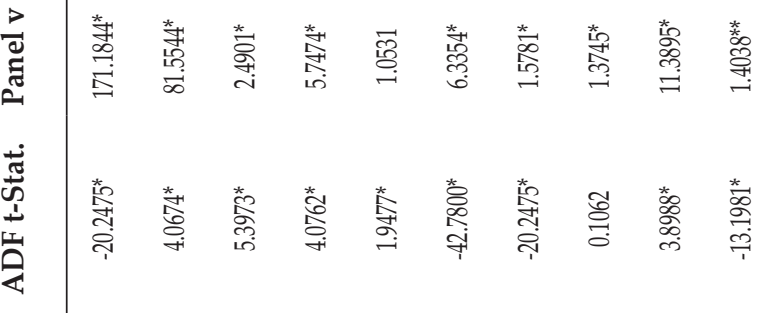

过艺造

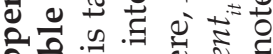

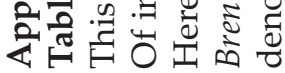


=

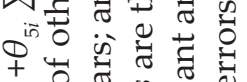

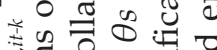
“串 竎

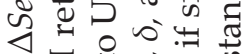

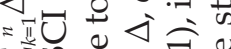

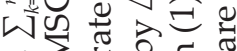

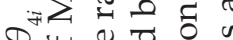
† प 000

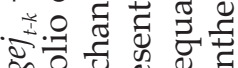

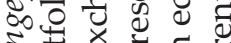

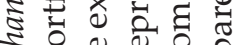
ปิ

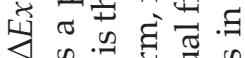
$=\pi \cdot 2 \cdot=0$

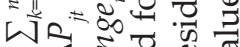
त्र है छ

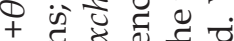
药 至㟧: ปั ज च की $=\pi \sum .00 \%$

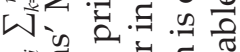
๑ + 全

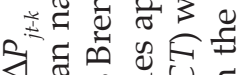
$\checkmark$. ำ क क

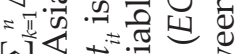

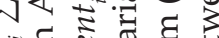

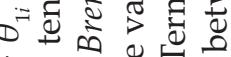

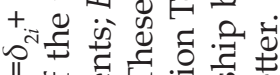

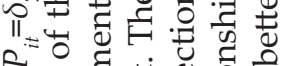

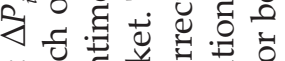
तิ व्य

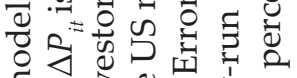
¿心

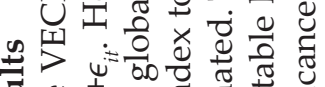
जै $\approx$ o 8 क क

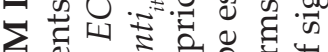

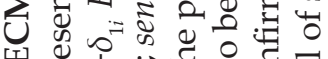

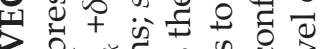
ن 00.

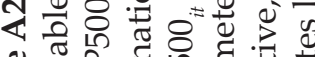
푸 $\frac{1}{10}$ है तै

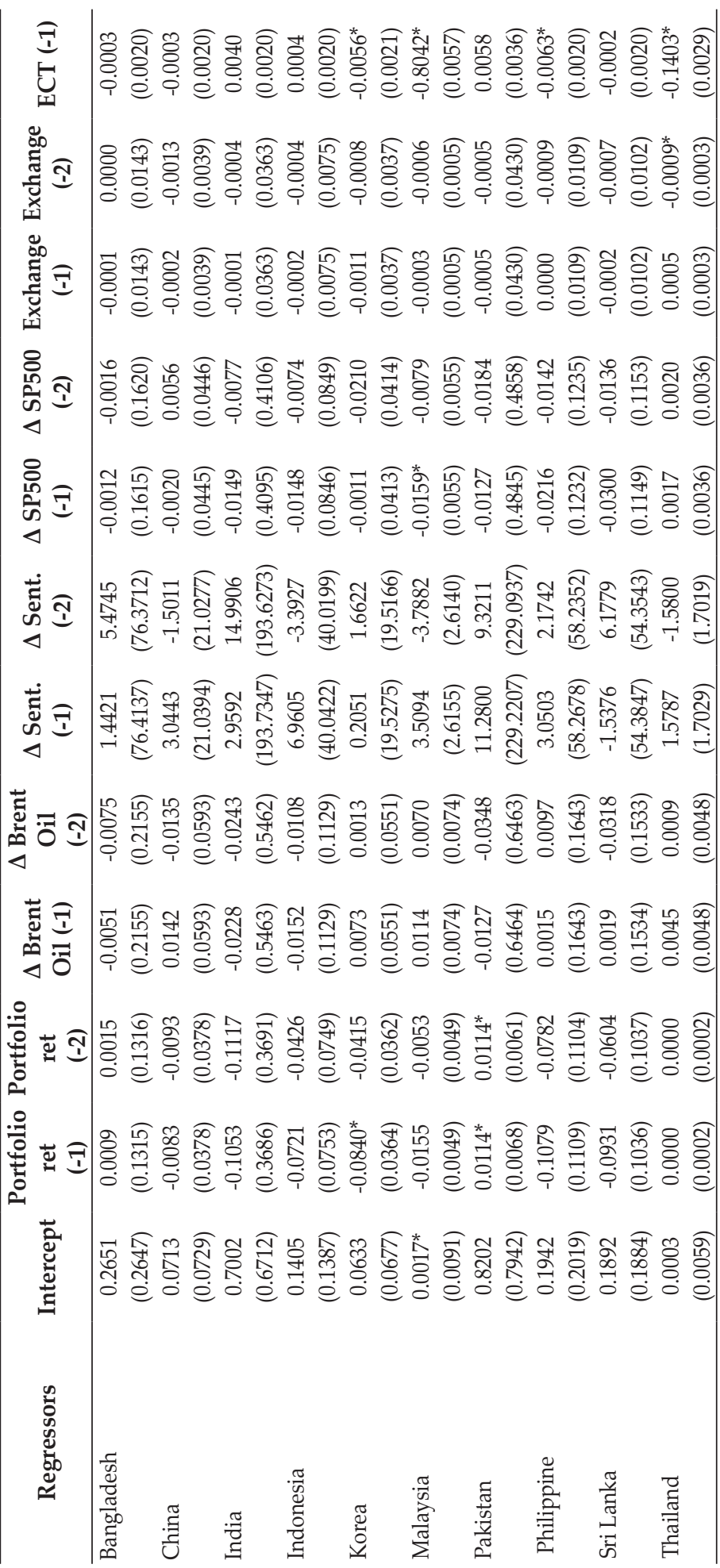


Table A3. Long-Run Regression Results

This table displays the long-run relationships depicted in equation (1): $P_{i t}=\delta_{1 i}+\theta_{1 i}$ $P_{i t}+\theta_{2 i}$ Brent $_{i t}+\theta_{3 i}$ Sentiments $_{i t}+\theta_{4 i}$ SEP $500_{i t}+\theta_{5 i}$ Exchange $_{i t}+\mu_{i t}$. Here, $P_{i t}$ is each of the ten Asian nations' MSCI; $P_{j t}$ is a portfolio of MSCI of other nine nations; senti $i_{i t}$ are global investor sentiments; Brent ${ }_{i t}$ is Brent oil price series; Exchange ${ }_{i t}$ is the exchange rate to US dollar; and $S \mathcal{E} P 500_{i t}$ is the price index to the US market. Note that the long-run estimation only relates to the cointegrated relationships depicted in equation (1). ${ }^{*}$ denotes significance at 5 percent or better. Values in parenthesis are standard errors. $3^{\text {rd }}, 5^{\text {th }}, 7^{\text {th }}, 9^{\text {th }}$ and $11^{\text {th }}$ column represent corresponding t-values for long-run results

\begin{tabular}{lcccccccccc}
\hline & \multicolumn{2}{c}{$\boldsymbol{P}_{j t}$} & \multicolumn{2}{c}{ Brent } & Sentiments & \multicolumn{2}{c}{ SP500 } & \multicolumn{2}{c}{ Exchange } \\
\hline \multicolumn{1}{l}{ DOLS Results } & & & & & & & & & & \\
\hline India & -3.2679 & -1.1701 & 0.2117 & 1.4821 & 1.7518 & 0.2220 & 5.2278 & 0.7839 & -0.0007 & -0.0333 \\
& $(2.7929)$ & & $(0.1428)$ & & $(7.8898)$ & & $(6.6687)$ & & $(0.0215)$ & \\
\multirow{2}{*}{ Korea } & -0.2261 & -0.8545 & $0.0292^{*}$ & 2.1254 & -0.0214 & -0.0283 & 0.5031 & 0.7859 & -0.0001 & -0.0292 \\
& $(0.2646)$ & & $(0.0137)$ & & $(0.7574)$ & & $(0.6401)$ & & $(0.0021)$ & \\
\multirow{2}{*}{ Malaysia } & $0.1238^{*}$ & 18.3791 & $0.0067^{*}$ & 19.1516 & $-0.1111^{*}$ & -5.7615 & 0.0177 & 1.0844 & -0.0001 & -0.0805 \\
& $(0.0067)$ & & $(0.0004)$ & & $(0.0192)$ & & $(0.0163)$ & & $(0.0000)$ & \\
\multirow{2}{*}{ Pakistan } & $3.4698^{*}$ & 254.3557 & 0.0134 & 0.3149 & 0.0402 & 0.0171 & 0.8805 & 0.4425 & -0.0002 & -0.0303 \\
& $(0.0136)$ & & $(0.0426)$ & & $(2.3521)$ & & $(1.9899)$ & & $(0.0064)$ & \\
\multirow{2}{*}{ Philippine } & $-0.8936^{*}$ & -1.0967 & 0.0670 & 1.6726 & 0.5234 & 0.2264 & 1.5534 & 0.7954 & -0.0004 & -0.0563 \\
& $(0.8151)$ & & $(0.0418)$ & & $(2.3114)$ & & $(1.9530)$ & & $(0.0063)$ & \\
\multirow{2}{*}{ Thailand } & 0.0001 & 0.0012 & $-0.0495^{*}$ & -51.6104 & $0.8717^{*}$ & 16.4514 & 0.0421 & 0.9372 & 0.0007 & 4.7072 \\
& $(0.0004)$ & & $(0.0010)$ & & $(0.0530)$ & & $(0.0448)$ & & $(0.0002)$ & \\
\hline
\end{tabular}


This page is intentionally left blank 